\title{
Pectinase production by Neurospora crassa: purification and biochemical characterization of extracellular polygalacturonase activity
}

\author{
Maria de Lourdes T. M. Polizeli, João A. Jorge and Héctor F. Terenzi* \\ Departamento de Biologia, Faculdade de Filosofia, Ciências e Letras de Ribeirão Preto, Universidade de São Paulo, \\ 14049 Ribeirão Preto, São Paulo, Brazil
}

(Received 14 December 1990; revised 10 April 1991; accepted 22 April 1991)

\begin{abstract}
The production of pectinase was studied in Neurospora crassa, using the hyperproducer mutant exo-1, which synthesized and secreted five to six times more enzyme than the wild-type. Polygalacturonase, pectin lyase and pectate lyase were induced by pectin, and this induction was glucose-repressible. Polygalacturonase was induced by galactose four times more efficiently than by pectin; in contrast the activity of lyases was not affected by galactose. The inducing effect of galactose on polygalacturonase was not glucose-repressible. Extracellular pectinases were separated by ion exchange chromatography. Pectate and pectin lyases eluted into three main fractions containing both activities; polygalacturonase eluted as a single, symmetrical peak, apparently free of other protein contaminants, and was purified 56-fold. The purified polygalacturonase was a monomeric glycoprotein (38\% carbohydrate content) of apparent molecular mass 36.6-37.0 kDa (Sephadex G-100 and urea-SDS-PAGE, respectively). The enzyme hydrolysed predominantly polypectate. Pectin was also hydrolysed, but at $7 \%$ of the rate for polypectate. $K_{\mathrm{m}}$ and $V_{\max }$ for polypectate hydrolysis were $5.0 \mathrm{mg} \mathrm{ml}^{-1}$ and $357 \mu \mathrm{mol} \mathrm{min}^{-1}(\mathrm{mg} \text { protein) })^{-1}$, respectively. Temperature and $\mathrm{pH}$ optima were $45^{\circ} \mathrm{C}$ and 6.0, respectively. The purified polygalacturonase reduced the viscosity of a sodium polypectate solution by $50 \%$, with an increase of $7 \%$ in reducing sugar groups. The products of hydrolysis at initial reaction times consisted of oligogalacturonates without detectable monomer. Thus, the purified Neurospora crassa enzyme was classified as an endopolygalacturonase [poly(1,4- $\alpha$-D-galacturonide) glycanohydrolase; EC 3.2.1.15].
\end{abstract}

\section{Introduction}

The biological decomposition of pectin is an important process in biomass degradation. In nature, pectin is degraded by enzymic systems produced by a wide variety of saprophytic and phytopathogenic micro-organisms, including bacteria and fungi (Rombouts \& Pilnik, 1980). Pectinases hydrolyse pectin by different mechanisms, and are divided into those which attack methyl-esterified pectin (pectinic acids) and those which act on de-esterified pectin (pectic acids). Within each class can be distinguished hydrolases and lyases, which may cleave randomly (endo-acting) or at the extremities (exo-acting) of these polymers (White \& Kennedy, 1988).

One of the best-characterized pectolytic activities is that of endopolygalacturonase (poly $(1,4-\alpha-D$-galacturonide) glycanohydrolase; EC 3.2.1.15), a hydrolase which randomly cleaves glycosidic bonds of pectic acids or polygalacturonates, producing mono-, di-, and oligo-

Abbreviation: CMC, carboxymethylcellulose. galacturonates as final hydrolysis products. This enzyme has been purified and characterized from several fungi, including Aspergillus sp. (Aguilar \& Huitron, 1987), Botrytis cinerea (Leone \& Van Den Heuvel, 1987), Fusarium moniliforme (De Lorenzo et al., 1987), Rhizoctonia solani Kuhn (Marcus et al., 1986), Rhizopus stolonifer (Manachini et al., 1987), Trichoderma köningii (Fanelli et al., 1978) and Verticillium albo-atrum (Wang \& Keen, 1970).

The long-standing interest in pectinases resides in their role in the invasion of plant tissues by phytopathogens, the spoilage of fruit and vegetables and also in their food processing and plant biotechnology applications. The present investigation was attempted to characterize the pectolytic system of Neurospora crassa. This fungus is neither a phytopathogen, nor commonly regarded as of practical value in terms of enzymic productivity. Nevertheless, Neurospora crassa is probably the best-studied filamentous fungus in terms of biochemistry and genetics, and is also a valuable model system for molecular research. Neurospora crassa 
produces many hydrolytic enzymes, including cellulases (Eberhart et al., 1977; Yazdi et al., 1990), nucleases (Lindberg \& Drucker, 1984), proteases (Cohen \& Drucker, 1977), amylase (Sigmund et al., 1985), xylanase (Mishra et al., 1984), glucosidases (Eberhart \& Beck, 1973) and others, which have been the focus of intense research. These studies are relevant to our understanding of the genetics, enzymology, regulatory properties and other characteristics of fungal hydrolases. Nevertheless, our knowledge of Neurospora crassa pectinases lags well behind that of other hydrolases. After an earlier study (Roboz et al., 1952) describing an extracellular activity, designated 'pectin depolymerase', which hydrolyses pectin, producing mainly low-molecular-weight polyuronides, no further studies related to pectinase activity of $N$. crassa were published.

Here, we describe pectolytic enzymes produced by Neurospora crassa mycelium incubated in pectin as the inducer carbon source, and report the purification and partial biochemical characterization of an extracellular polygalacturonase activity.

\section{Methods}

Neurospora crassa strains and culture conditions. The $N$. crassa strains used in this work, FGSC 424 (wild-type) and FGSC 2256 (exo-l), were a gift from the Fungal Genetics Stock Center (Kansas City, Kansas, USA). These strains were propagated on slants of solid Vogel (1964) medium supplemented with $2 \%(w / v)$ sucrose. Liquid cultures were prepared in $250 \mathrm{ml}$ Erlenmeyer flasks containing $50 \mathrm{ml}$ Vogel's minimal medium supplemented with $2 \%(\mathrm{w} / \mathrm{v})$ glucose or other carbon sources, as indicated for each experiment. The inoculum consisted of suspensions of macroconidia $\left(5 \times 10^{5} \mathrm{ml}^{-1}\right)$. Cultures were incubated with agitation ( 140 r.p.m.) at $30^{\circ} \mathrm{C}$. For induction of pectolytic activities a two-step culture procedure was used: the fungus was first grown in glucose medium for $24 \mathrm{~h}$ (step I) and was then transferred to induction medium and incubated for an additional $48 \mathrm{~h}$ (step II). The cultures were harvested by filtration (Whatman no. 1), and the culture filtrates and mycelia were saved for enzyme determination. Before the enzyme assay, the crude preparations were dialysed overnight against $50 \mathrm{~mm}$-sodium acetate buffer, $\mathrm{pH} 5 \cdot 5$. The purification procedure for extracellular pectolytic activities is presented in Results.

Preparation of crude extracts. Mycelial pads were ground in a porcelain mortar with twice their weight of sea sand at $0{ }^{\circ} \mathrm{C}$. After cell breakage of more than $90 \%$ was achieved, $10 \mathrm{ml}$ sodium acetate buffer was added, and the slurry was centrifuged at $15900 \mathrm{~g}$ for $20 \mathrm{~min}$. The crude extract supernatant was used for enzyme determinations.

Enzyme assays. Polygalacturonase activity was assayed with sodium polypectate as a substrate by measuring the amount of reducing sugar released (Miller, 1959), as previously described (Polizeli et al., 1990). An enzyme unit is the amount which releases reducing sugar at an initial rate of $1 \mu \mathrm{mol} \mathrm{m^{-1 }}$ at $37^{\circ} \mathrm{C}$, using monogalacturonic acid as the standard. Viscosity measurements were carried out at $37^{\circ} \mathrm{C}$ in Ostwald viscosimeters with $2 \%$ sodium polypectate solution, according to Roboz et al. (1952). The enzyme action was expressed as a percentage change in viscosity. Pectate lyase activity was monitored in a Beckman DU-7 recording spectrophotometer, by measuring the increase in $A_{232}$ due to 4,5-unsaturated reaction products (Nagel \& Anderson, 1965) according to Collmer et al. (1988). One unit of enzyme forms $1 \mu \mathrm{mol}$ 4,5-unsaturated product $\mathrm{min}^{-1}$ under the conditions of the assay. Pectin lyase was measured colorimetrically by the reaction between unsaturated products of pectin degradation and thiobarbituric acid (Ayers et al., 1966) according to the procedure described by Pitt (1988). One enzyme unit causes a change in absorbance of 0.01 under the conditions of the assay.

Polyacrylamide gel electrophoresis. Electrophoresis under nondenaturing conditions was carried out by the method of Davis (1964). Urea $(8 \%)$ sodium-dodecyl-sulphate-polyacrylamide $(5 \%)$ gel electrophoresis (urea-SDS-PAGE) was carried out according to Swank \& Munkres (1971). Molecular mass markers were: bovine serum albumin, $66 \mathrm{kDa}$; ovalbumin, $45 \mathrm{kDa}$; deoxyribonuclease, $31 \mathrm{kDa}$ and trypsin inhibitor, 20.1 kDa.

Gel filtration. The molecular mass of the purified polygalacturonase was estimated by filtration in a Sephadex G-100 $(1.5 \times 60 \mathrm{~cm})$ column equilibrated with $10 \mathrm{mM}-\mathrm{Tris} / \mathrm{HCl}(\mathrm{pH} \mathrm{7.5)}$ plus $100 \mathrm{mM}-\mathrm{KCl}$. Elution $\left(12.0 \mathrm{ml} \mathrm{h}^{-1}\right)$ was carried out with the same buffer and fractions $(1.5 \mathrm{ml})$ were collected and analysed for polygalacturonase activity. Void volume $(34 \mathrm{ml})$ was determined with blue dextran. The following proteins were used as molecular mass markers: alcohol dehydrogenase, $150 \mathrm{kDa}$; bovine serum albumin, $66 \mathrm{kDa}$; carbonic anhydrase, $29 \mathrm{kDa}$ and cytochrome $c(12.4 \mathrm{kDa})$.

Chromatographic separation of the hydrolysis products. Hydrolysis products from sodium polypectate by the purified polygalacturonase were analysed by thin-layer chromatography on silica gel G-60, using ethyl acetate/acetic acid/formic acid/water $(9: 3: 1: 4$, by vol.) as the mobile phase system. Sugars were detected with $0.2 \%$ orcinol in sulphuric acid-methanol (10:90 ml) (Fontana et al., 1988).

Determination of neutral carbohydrate and protein. Total neutral carbohydrate in protein samples was estimated by the phenol/sulphuric acid method of Dubois et al. (1956) using mannose as standard. Protein was determined by the Lowry method using bovine serum albumin as standard.

Chemicals. Polygalacturonic acid sodium salt, pectin $(8.9 \%$ methoxy content), other polysaccharides and monosaccharides, DEAEcellulose, carboxymethyl-cellulose, PAGE reagents and molecular mass markers were purchased from Sigma. Sephadex G-100 and Bio-Gel P-60 were obtained from Pharmacia and Bio-Rad, respectively. Silica Gel G was obtained from Merck. All other reagents were of analytical grade.

\section{Results}

\section{Production of pectolytic activity}

A significant level of polygalacturonic acid-degrading activity [ 1.6 units $\left.(\mathrm{mg} \text { wet } \mathrm{wt})^{-1}\right]$ was present, among other hydrolases, on the outer surface of intact conidiospores. Most, if not all, of this activity was extractable with water; e.g. two cycles of vortexing and centrifugation of a conidial suspension removed $84 \%$ of the original activity present on the cells. Interestingly, the polygalacturonic-acid-degrading activity of conidia increased considerably [5.0 units (mg wet $\mathrm{wt})^{-1}$ ] when the conidiospores were grown in pectin-supplemented solid medium. This substrate induction effect was not observed for other conidial exoenzymes tested, includ- 


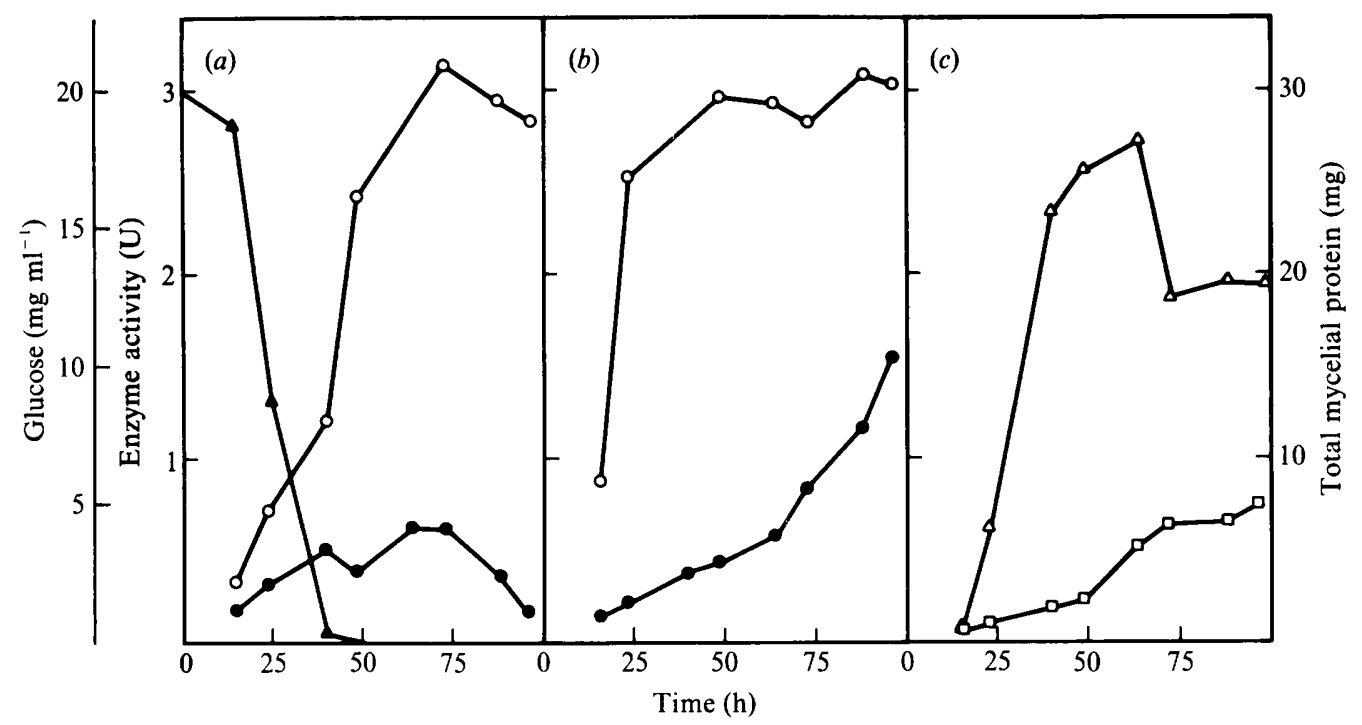

Fig. 1. Time-course development of polygalacturonic-acid-degrading activity in wild-type $N$. crassa cultures incubated with $2 \%$ glucose $(a)$ or $1 \%$ pectin $(b)$ as carbon source. Symbols: $(O)$ activity in the culture filtrate; $(\bullet)$ activity in mycelium extracts; $(\mathbf{\Delta})$ glucose concentration. Panel $(c)$ growth (mg total protein) of cultures grown in glucose $(\triangle)$ and in pectin $(\square)$. Enzyme activity was estimated on the basis of reducing sugar production using sodium polypectate as substrate, as described in Methods.

ing amylase, cellulases, glycosidases and alkaline phosphatase (data not shown).

In liquid medium supplemented with pectin as the sole carbon source, $N$. crassa grew slowly (Fig. $1 c$ ) and at the end of the growth phase $(65 \mathrm{~h})$ the mycelial yield was one-fourth of that of cultures grown in glucose-supplemented medium. For cultures grown with glucose as carbon source, polygalacturonic-acid-degrading activity was detected even before total disappearance of the sugar (Fig. $1 a$ ), and maximal activity was attained after $72 \mathrm{~h}$ incubation. On the other hand, polygalacturonicacid-degrading activity in pectin-supplemented cultures increased faster than in the glucose-supplemented ones (Fig. $1 b$ ), and reached its maximum value after $50 \mathrm{~h}$ incubation. At that time, the difference in specific polygalacturonic-acid-degrading activity between glucose-grown and pectin-grown cultures after $50 \mathrm{~h}$ of incubation was approximately 16-fold and decreased to about $3 \cdot 3$-fold by the end of the incubation period.

In view of the relatively poor mycelium growth in pectin-supplemented cultures, resulting in low yields of enzyme for purification purposes, a two-step culture procedure was employed for inducing the enzymes (see Methods). In this way, the yield of extracellular polygalacturonic-acid-degrading activity was improved from an average of 0.08 units $\mathrm{ml}^{-1}$ (cultures grown directly on pectin) to about 0.2 units $\mathrm{ml}^{-1}$ (two-step cultures). Further improvement in enzyme yield was achieved by using the exo-1 mutant strain, reportedly an hyperproductor of other hydrolases (Gratzner \& Sheenan, 1969). Under induct:on conditions, the production of polygalacturonic-acid-degrading activity of the mutant (about $1.1 \mathrm{U} \mathrm{ml}^{-1}$ in two-step cultures) was five to six times higher than that of the wild-type. All results presented hereafter were obtained with the exo-1 mutant strain.

\section{Effect of the carbon source on the production of pectolytic activities}

Table 1 shows the results of a series of two-step incubations of the exo- 1 mutant in several carbon sources. The culture filtrates were assayed for polygalacturonase, pectin lyase and pectate lyase. Incubation in pectin, polygalacturonate or monogalacturonate increased polygalacturonase activity about 13 -fold over the basal level (glucose-grown cultures or cultures incubated without a carbon source). Other carbon sources including starch, microcrystalline cellulose, carboxymethylcellulose, xylan, trehalose, raffinose or sucrose had no effect (not shown). The inductive effect of pectin (Table 1), polygalacturonate and monogalacturonate (not shown) was abolished if glucose was present in the medium. Galactose was a very effective inducer of polygalacturonic-acid-degrading activity (62-fold over basal values). Interestingly, the inductive effect of galactose was not abolished by the presence of glucose. 
Table 1. Effect of carbon sources on the production of extracellular polygalacturonase, pectate lyase and pectin lyase activities by the exo-I mutant strain

A two-step culture procedure as described in Methods was used. Carbon sources were added at $1 \%(w / v)$ concentration. Specific activities were calculated by dividing total enzyme units of the culture filtrate by the total protein $(\mathrm{mg})$ of the crude mycelial extract.

\begin{tabular}{lccc}
\hline \hline & \multicolumn{3}{c}{ Specific activity [U (mg protein $\left.)^{-1}\right]$} \\
\cline { 2 - 4 } \multicolumn{1}{c}{ Carbon source } & $\begin{array}{c}\text { Poly- } \\
\text { galacturonase }\end{array}$ & $\begin{array}{c}\text { Pectate lyase } \\
\left(\times 10^{3}\right)\end{array}$ & Pectin lyase \\
\hline Pectin & 0.79 & 12.3 & 3.79 \\
Sodium polypectate & 0.54 & 4.3 & ND \\
Monogalacturonic acid & 0.66 & $10 \cdot 5$ & ND \\
Galactose & 3.12 & 4.5 & ND \\
Galactose plus pectin & 2.13 & 7.7 & 1.77 \\
Glucose & 0.05 & 3.1 & ND \\
Pectin plus glucose & 0.05 & 2.1 & ND \\
Galactose plus glucose & 4.02 & 2.5 & ND \\
No carbon source added & 0.09 & ND & ND \\
\hline \hline
\end{tabular}

ND, not detected.

The activities of pectate lyase and pectin lyase were higher than basal activity in pectin-supplemented cultures. Glucose repressed the induction by pectin, while galactose had little or no effect on the level of these enzymes.

\section{Separation of pectolytic activities and purification of polygalacturonase}

All steps were carried out at $4{ }^{\circ} \mathrm{C}$ or below. Pectininduced cultures of the exo- 1 mutant were harvested by filtration. Routinely, $600 \mathrm{ml}$ culture filtrate was used for enzyme purification. The culture filtrate was added to three vols absolute ethanol $\left(-20^{\circ} \mathrm{C}\right)$ and stored overnight. Precipitated material was collected by centrifugation and dissolved in $10 \mathrm{ml} 50 \mathrm{~mm}$-sodium acetate buffer, $\mathrm{pH} 5.5$. The highly viscous solution was centrifuged to remove insoluble material, and the supernatant was passed through a Bio Gel P-60 column $(4.3 \times 51.0 \mathrm{~cm})$ equilibrated with the same buffer. Pectolytic activities (polygalacturonase, pectase lyase and pectin lyase) co-eluted in the void volume of the column (not shown). At this stage, the enzyme preparation was substantially free of carbohydrate (mostly pectin from the culture medium) and contained associated invertase and amylase activities. The pooled active fractions were dialysed overnight against $0.01 \mathrm{M}-\mathrm{Tris} / \mathrm{HCl}$ buffer, $\mathrm{pH} 7.5$, and applied to a DEAE-cellulose column $(1.7 \times 45.0 \mathrm{~cm})$ which had been equilibrated and washed with the same buffer. The pectolytic activities co-eluted with amylase in the void volume of the column while invertase was bound to the resin and was eluted by increasing the ionic strength of the buffer $(110 \mathrm{~mm}$ $\mathrm{NaCl}$ ). The pooled active fractions containing pectolytic activities were dialysed overnight against $10 \mathrm{mM}$-sodium acetate buffer, $\mathrm{pH} 5.5$, and applied to a CM-cellulose column $(1.2 \times 17.0 \mathrm{~cm})$ equilibrated with the same buffer. The column was first eluted with three vols of the equilibrating buffer followed by $200 \mathrm{ml}$ of a linear sodium chloride gradient $(0-0.5 \mathrm{M})$ dissolved in the same buffer (Fig. 2). Amylase activity did not bind to the resin and was eluted with a bulk of protein, in the equilibrating buffer. The salt gradient led to separation of pectolytic activities into four peaks (Fig. 2). Polygalacturonase eluted at $0.235 \mathrm{M}-\mathrm{NaCl}$ as a single, symmetrical peak (peak III) which contained $33.5 \%$ of the activity initially present in the crude filtrate. Pectin lyase and pectate lyase co-eluted in a minor and two major peaks of activity at 0.125 (peak I), 0.152 (peak II) and 0.264 (peak IV) M- $\mathrm{NaCl}$, respectively. The relative activities of pectate lyase and pectin lyase in peaks I, II and IV, was variable (Table 3). Pectate lyase was predominant in peak II $(62 \%$ of total activity eluted from the column, with a purification factor of 33.3 ) while pectin lyase was evenly distributed into peaks II and IV. The sum of activities of peaks I, II, and IV demonstrates that the recovery of pectate lyase and pectin lyase, relative to the activity in the crude filtrate, was approximately $25 \%$ and $12 \%$, respectively. The pooled fractions of peak IV also contained considerable polygalacturonase activity $(15 \%$ of total in CMC eluates). The combined fractions with polygalacturonase activity (fractions 35-39) of peak III exhibited a specific activity of $298.65 \mathrm{U}$ (mg protein) ${ }^{-1}$ and a purification factor of approximately 56 (Table 2). PAGE $(6.0 \%, \mathrm{w} / \mathrm{v})$ of the purified polygalacturonase revealed a single protein band after staining with Coomassie Blue (not shown), suggesting that the enzyme preparation was homogeneous.

The carbohydrate content of the purified polygalacturonase was estimated as $38 \%$ by the phenol/ sulphuric acid method. Urea-SDS-PAGE produced an apparent molecular mass of approximately $37 \mathrm{kDa}$ for the purified enzyme (results not shown). Gel filtration in Sephadex G-100 indicated an apparent molecular mass of approximately $36.6 \mathrm{kDa}$ (results not shown). These results suggested that the enzyme was a monomeric glycoprotein.

\section{Catalytic properties and kinetic parameters}

The purified polygalacturonase was highly specific to sodium polypectate. Pectin was also hydrolysed, but at a rate $7-8 \%$ of that for sodium polypectate. The enzyme was totally inactive on starch, microcrystalline cellulose, xylan, trehalose, sucrose and raffinose. The temperature 


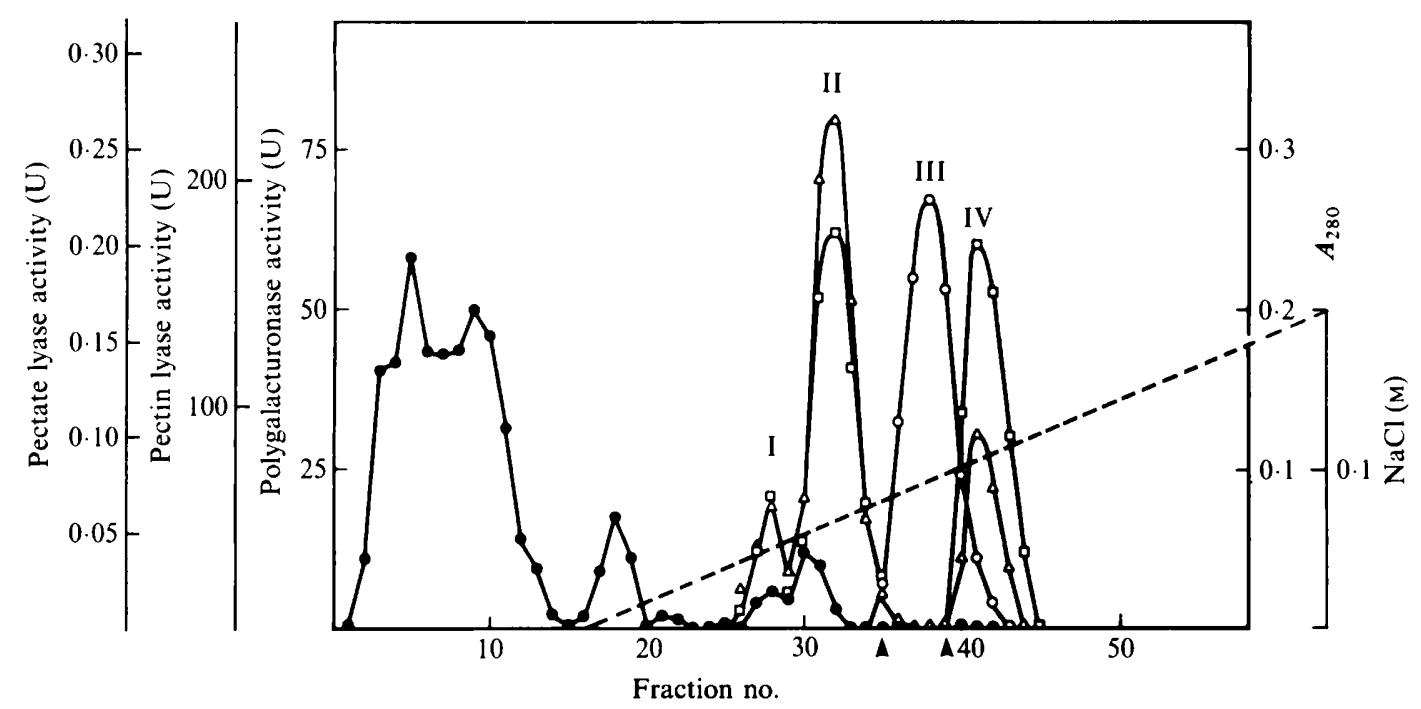

Fig. 2. Separation of pectolytic activity on CM-cellulose. Symbols: $(\bullet) A_{280} ;(O)$ polygalacturonase; $(\triangle)$ pectate lyase; $(\square)$ pectin lyase; $(--) \mathrm{NaCl}$ gradient. The arrows indicate fractions pooled for polygalacturonase characterization. Other details are described in the Methods and Results sections.

Table 2. Purification of extracellular polygalacturonase activity

These results correspond to the experiment shown in Fig. 2.

\begin{tabular}{|c|c|c|c|c|c|c|}
\hline Step & $\begin{array}{l}\text { Volume } \\
(\mathrm{ml})\end{array}$ & $\begin{array}{l}\text { Total protein } \\
(\mathrm{mg})\end{array}$ & $\begin{array}{c}\text { Total activity } \\
\text { (U) }\end{array}$ & $\begin{array}{l}\text { Specific activity } \\
{\left[\mathrm{U}(\mathrm{mg} \text { protein })^{-1}\right]}\end{array}$ & $\begin{array}{l}\text { Purification factor } \\
\text { (-fold) }\end{array}$ & $\begin{array}{c}\text { Yield } \\
(\%)\end{array}$ \\
\hline Crude filtrate & $600 \cdot 00$ & $144 \cdot 37$ & 768.00 & $5 \cdot 32$ & - & $100 \cdot 00$ \\
\hline $70 \%$ Ethanol precipitate & $10 \cdot 50$ & $45 \cdot 78$ & 328.09 & $7 \cdot 17$ & $1 \cdot 35$ & $42 \cdot 72$ \\
\hline Pooled BioGel P-60 eluates & $127 \cdot 00$ & $19 \cdot 81$ & $530 \cdot 16$ & $26 \cdot 76$ & $5 \cdot 03$ & 69.03 \\
\hline Pooled DEAE-cellulose eluates & 134.00 & $16 \cdot 96$ & $495 \cdot 28$ & $29 \cdot 20$ & $5 \cdot 49$ & $64 \cdot 49$ \\
\hline Pooled CM-cellulose eluates (Peak III) & $15 \cdot 00$ & 0.72 & 215.03 & 298.65 & $56 \cdot 14$ & 28.00 \\
\hline
\end{tabular}

Table 3. Purification of pectate lyase and pectin lyase activities

These results correspond to the experiment shown in Fig. 2.

\begin{tabular}{|c|c|c|c|c|c|c|}
\hline \multirow[b]{2}{*}{ Step } & \multicolumn{3}{|c|}{ Pectate lyase } & \multicolumn{3}{|c|}{ Pectin lyase } \\
\hline & $\begin{array}{c}\text { Total activity } \\
\text { (U) }\end{array}$ & $\begin{array}{l}\text { Yield } \\
(\%)\end{array}$ & $\begin{array}{l}\text { Purification factor } \\
\text { (-fold) }\end{array}$ & $\begin{array}{c}\text { Total activity } \\
\text { (U) }\end{array}$ & $\begin{array}{l}\text { Yield } \\
(\%)\end{array}$ & $\begin{array}{l}\text { Purification factor } \\
\text { (-fold) }\end{array}$ \\
\hline Crude filtrate & $4 \cdot 80$ & $100 \cdot 00$ & - & $10169 \cdot 00$ & $100 \cdot 00$ & - \\
\hline Peak I (CMC) & $0 \cdot 14$ & $2 \cdot 92$ & 13.03 & $115 \cdot 60$ & $1 \cdot 14$ & 4.97 \\
\hline Peak II (CMC) & 0.76 & $15 \cdot 83$ & $33 \cdot 33$ & $539 \cdot 20$ & $5 \cdot 30$ & 11.03 \\
\hline Peak IV (CMC) & $0 \cdot 32$ & 6.67 & $23 \cdot 33$ & $606 \cdot 0$ & 5.96 & $20 \cdot 73$ \\
\hline
\end{tabular}

and $\mathrm{pH}$ optima of the purified polygalacturonase were $45^{\circ} \mathrm{C}$ and $6 \cdot 0$, respectively. An Arrhenius plot showed that the purified enzyme had an $E_{\mathrm{a}}$ value of $4.0 \mathrm{Kcal}$ $(16.8 \mathrm{~kJ}) \mathrm{mol}^{-1}$ for the hydrolysis of sodium polypectate. At temperatures above $50{ }^{\circ} \mathrm{C}$, and in the absence of its substrate, the purified polygalacturonase was rapidly denatured. The estimated half-life of the enzyme at $50{ }^{\circ} \mathrm{C}$ was about $4 \mathrm{~min}$ and, at $60^{\circ} \mathrm{C}$, about $1.2 \mathrm{~min}$. The purified enzyme showed good stability at $-20{ }^{\circ} \mathrm{C}$, losing less than $10 \%$ activity after a month. The activity of the purified polygalacturonase was not significantly affected by magnesium chloride, magnesium sulphate, zinc chloride, mercury chloride, barium chloride, EDTA or $\beta$-mercaptoethanol (all at $2.5 \mathrm{~mm}$ ). On the other hand, $2.5 \mathrm{mM}$-calcium chloride or copper sulphate inhibited the enzyme by approximately $79 \%$ and $67 \%$ respectively. 


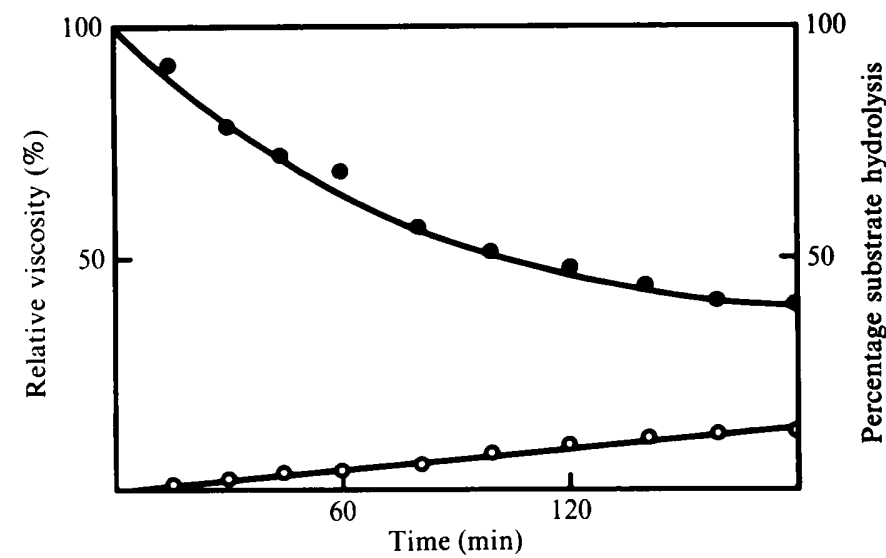

Fig. 3. Viscosity change and sodium polypectate hydrolysis by the purified polygalacturonase as a function of time. Symbols: $(\bullet)$ relative viscosity $(\%) ;(0)$ hydrolysis of glycosidic bonds $(\%$ of nominal monomer concentration). Details are given in Methods.

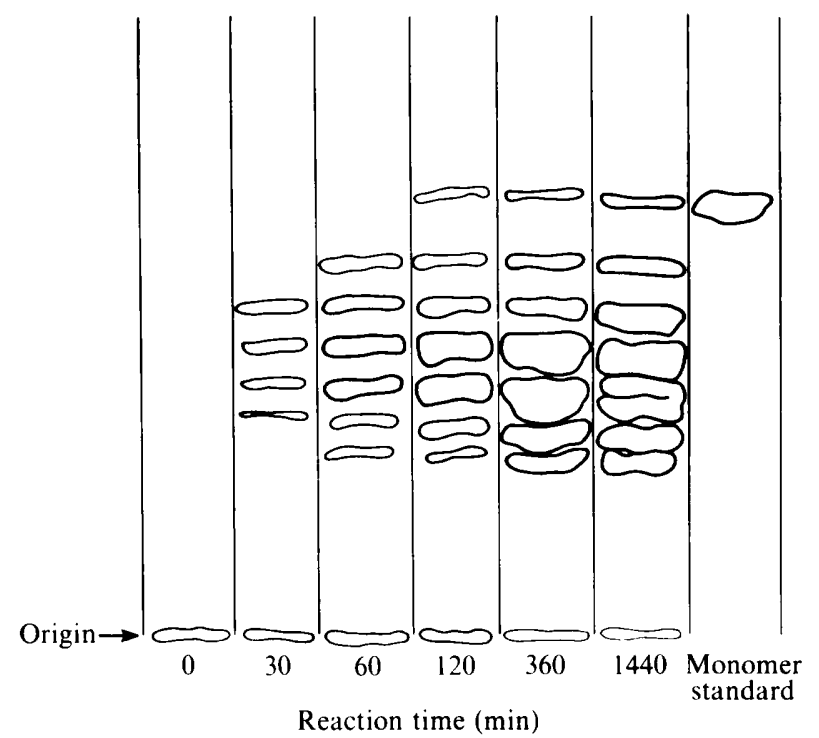

Fig. 4. Silica gel thin-layer chromatogram of the reaction products of the purified polygalacturonase with sodium polypectate. The incubation mixture $(1 \mathrm{ml})$ contained $1 \%$ sodium polypectate, $50 \mathrm{~mm}$-sodium acetate buffer, $\mathrm{pH} 5.5$, and 3.0 units of polygalacturonase. Samples ( 5 to $15 \mu \mathrm{l}$ ) were withdrawn from the reaction mixture, boiled and spotted on the chromatogram at the indicated times (see Methods).

$K_{\mathrm{m}}$ and $V_{\max }$ were determined at $37^{\circ} \mathrm{C}$ using sodium polypectate concentrations ranging from 0.5 to $20 \mathrm{mg} \mathrm{ml}^{-1}$. Lineweaver-Burk plots gave an apparent $K_{\mathrm{m}}$ of $5.0 \mathrm{mg} \mathrm{ml}^{-1}$ and an apparent $V_{\max }$ of $357 \mu \mathrm{mol} \mathrm{min}^{-1}$ (mg protein) $)^{-1}$. The purified enzyme appeared to be inhibited by high substrate concentrations.

\section{Mechanism of action}

The viscosimetric assay and the identification of hydrolysis products were used to determine the mechanism of action of the purified polygalacturonase on sodium polypectate. Fig. 3 shows that the time required for $50 \%$ decrease in viscosity of a $2.0 \%(\mathrm{w} / \mathrm{v})$ sodium polypectate solution at $37^{\circ} \mathrm{C}$ was approximately $100 \mathrm{~min}$, at which time about $7 \%$ of the total galacturonide bonds had been hydrolysed. These results suggested a random mechanism of hydrolysis of sodium polypectate by the purified polygalacturonase. Thin layer chromatography of the products of hydrolysis provided further evidence for this hypothesis. As shown in Fig. 4, oligogalacturonates accumulated initially, but the monomer was found in the hydrolysate only after reaction for $2 \mathrm{~h}$. These results suggested that the $N$. crassa purified enzyme was an endopolygalacturonase [poly(1,4- $\alpha$-D-galacturonide)glycanohydrolase; EC 3.2.1.15].

\section{Discussion}

The occurrence of constitutive polygalacturonase activity at the outer layer of ungerminated conidia of $N$. crassa is not unique among fungi. Similar observations have been made on spores of some phytopathogenic fungi such as Botrytis cinerea (Leone \& Van Den Heuvel, 1987) and Geotrichum candidum (Barash \& Klein, 1969), in which the presence of the enzyme has been related with the process of invasion of the plant host. In $N$. crassa, the constitutive polygalacturonase activity of conidia provides the cells with an inherent capacity for using pectic substances as a source of carbon during germination. In addition, the constitutive polygalacturonase activity of conidia may contribute to the induction of pectinase synthesis, by degrading pectin to low-molecular-mass products which may act as inducers when taken up by the cells. The $N$. crassa cell wall seems to contribute to the regulation of polygalacturonase induction, because this enzyme is made constitutively and is not glucose-repressible in spheroplasts of a 'slime' strain (Polizeli et al., 1990). The wall-less 'slime' cells also produce other hydrolases constitutively, including invertase, aryl- $\beta$-glucosidase, alkaline protease (Pietro et $a l ., 1989$ ), alkaline phosphatase (Burton \& Metzenberg, 1974), cellulase and xylanase (Polizeli et al., 1990).

$N$. crassa grew well on organic matter rich in pectic substances, such as orange peel (data not shown), but grew poorly on minimal medium supplemented with pectin as the sole source of carbon. These observations have been reported by Roboz et al. (1952) and were reproduced in the present study. Glucose-grown cultures exhibited a relatively high basal activity of pectinase, but 
this activity was increased by pectin, polygalacturonic acid and mono-galacturonic acid. Other polysaccharides such as microcrystalline cellulose, carboxymethyl cellulose, xylan or starch failed to induce pectinases. The inductive effect of pectin and related compounds was repressed by glucose. In these aspects, the carbon-source effects on pectinase production by $N$. crassa were essentially similar to those reported for other fungi (Rombouts \& Pilnik, 1980).

$N$. crassa polygalacturonase was induced 4-5 times more efficiently by galactose than by pectin; however, galactose did not increase pectate lyase or pectin lyase activities. Galactose induction of polygalacturonase was not repressed by glucose. This selective induction of polygalacturonase by galactose, contrasting with the simultaneous induction of polygalacturonase, pectate lyase and pectin lyase by pectin, suggests that the pectinases of $N$. crassa, like the enzymes of Rhizoctonia solani (Lisker et al., 1975) and Verticillium albo-atrum (Cooper \& Wood, 1973) are not necessarily co-regulated. Alternatively, the galactose-induced and the pectininduced polygalacturonase may be products of different, independently controlled genes. A detailed biochemical characterization of the galactose-induced polygalacturonase should clarify this question.

On average, about $90 \%$ of the pectolytic activity produced by induced mycelium of $N$. crassa was released into the culture medium. The remaining activity, recovered in the supernatants of crude cell extracts, may either be cytosolic enzyme, or extracellular enzyme trapped in the periplasm.

The extracellular pectinases produced by pectininduced mycelium were separated into several components by ion exchange chromatography on CMC. The enzyme sample applied to the CMC column had been previously subjected to gel filtration in BioGel P 60 and DEAE-cellulose chromatography to remove contaminating activities. It is noteworthy that polygalacturonase, pectate lyase and pectin lyase co-eluted in the void volume of the BioGel P 60 column, because the apparent molecular mass of polygalacturonase $(37 \mathrm{kDa})$ and that of pectate and pectin lyase (approximately $37 \mathrm{kDa}$ and $50 \mathrm{kDa}$, respectively; not shown) was within the fractionation range of the gel. Perhaps the enzymes in the crude medium formed aggregates, either through protein-protein or protein-carbohydrate-protein interactions, as reported for the pectinases of Fusarium oxysporum (Swinburne \& Corden, 1967) and Geotrichum candidum (Barash et al., 1984). Titrimetric assays applied to samples of crude filtrates of induced cultures failed to demonstrate any methyl esterase activity. We have no explanation for that, because this activity should be a prerequisite for effective action of polygalacturonase on pectin. Pectate lyase and pectin lyase activities co-eluted in three main peaks from the CMC column and their characterization was not pursued further. Polygalacturonase eluted as a single, symmetrical peak.

Polygalacturonase activity was purified 56-fold and the enzyme preparation was apparently homogeneous. The enzyme was a monomeric glycoprotein with a molecular mass of about $37 \mathrm{kDa}$ and $38 \%$ carbohydrate. Its catalytic properties were very close to those of the partially purified (11.7-fold) extracellular 'pectin depolymerase' of $N$. crassa described by Roboz et al. (1952). 'Pectin depolymerase' has as $\mathrm{pH}$ optimum of $5 \cdot 5-6.0$, is $50 \%$ inactivated by $1 \mathrm{~h}$ incubation at $40{ }^{\circ} \mathrm{C}$ and fully inactivated at $70^{\circ} \mathrm{C}$, and decreases the viscosity of a polypectate solution by $50 \%$ with a release of reducing sugar groups of only $2 \%$. Roboz et al. (1952) considered at the time that the $N$. crassa enzyme was a new enzyme, different from other polygalacturonases. Indeed, these authors compared the activity of 'pectin depolymerase' with Pectinol, a commercial Aspergillus niger preparation containing a mixture of polygalacturonase activities (Cooke et al., 1976), which produced mainly monomer as the final reaction product. In contrast, 'pectin depolymerase' accumulated lowmolecular-mass polyuronides. It seems likely that the 'pectin depolymerase' described by Roboz et al. (1952) and the endopolygalacturonase reported in the present study are the same enzyme. A noted difference between the two enzymes, however, was that 'pectin depolymerase' attacks pectin and sodium polypectate with the same efficiency (Roboz et al., 1952), while the purified polygalacturonase hydrolysed pectin at a rate $7-8 \%$ of sodium polypectate, which is typical of endopolygalacturonases. This discrepancy could be attributed to contaminating activities in the 'pectin depolymerase' preparation used by Roboz et al. (1952).

Some properties of the $N$. crassa purified polygalacturonase such as glycoproteic nature, molecular mass, specific activity and ability to hydrolyse polypectate rather than pectin resemble those of other fungal polygalacturonases (Rombouts \& Pilnik, 1980). However, the pH optimum of the $N$. crassa enzyme (6.0) was somewhat higher than most other similar enzymes (pH 5.0 or below) but similar to that of the endopolygalacturonase of Verticillium albo-atrum $(\mathrm{pH} 6.5$; Wang \& Keen, 1970) and Botrytis cinerea ( $\mathrm{pH} 6.0$; Martínez et al., 1988). The $K_{\mathrm{m}}$ for hydrolysis of polypectate of most fungal polygalacturonases is $<1 \mathrm{mg} \mathrm{ml}^{-1}$ (Rombouts \& Pilnik, 1980). Thus, the $N$. crassa enzyme $K_{\mathrm{m}}$ $\left(5.0 \mathrm{mg} \mathrm{ml}^{-1}\right)$ was unusually high, as is that of a polygalacturonase produced by Tricladium splendens $\left(K_{\mathrm{m}}\right.$ $4.3 \mathrm{mg} \mathrm{ml}^{-1}$; Chamier \& Dixon, 1982).

The molecular characterization of fungal pectolytic enzymes and their genes is not as advanced as, for instance, that of the cellulolytic system. Reports have 
recently appeared in the literature concerning the molecular characterization of pectolytic genes of Aspergillus niger (Gysler et al., 1990; Khanh et al., 1990; Ruttkowski et al., 1990) but, as far as we are aware, no similar studies in other fungi have been reported. Thus, we would like to suggest that the apparent biochemical simplicity of $N$. crassa polygalacturonase (e.g. single polypeptide; no apparent isoforms) and its straightforward purification procedure, allied with the recent development of molecular cloning techniques in this fungus, may constitute a useful model system for investigating this important family of biomass-degrading hydrolases.

This work was supported by grants from Financiadora de Estudos e Projetos (FINEP) Fundação de Amparo a Pesquisa do Estado de São Paulo (FAPESP) No. 89/1585-1 e Conselho Nacional de Pesquisa (CNPq). M.L.T.M.P. received a graduate (doctoral) fellowship from CNPq. J. A. J. and H.F.T. are research Fellows of CNPq. This work is part of a thesis submitted by M.L.T.M.P. to the Department of Biochemistry of the School of Medicine of Ribeirão Preto (University of São Paulo) in partial fulfilment of the requirements for the doctoral degree. We thank Carlos de Carvalho Almada and Mauricio de Oliveira for technical assistance.

\section{References}

Aguilar, G. \& Huitron, C. (1987). Stimulation of the production of extracellular pectinolytic activities of Aspergillus sp. by galacturonic acid and glucose addition. Enzyme and Microbial Technology 9, 690-696.

Ayers, W. A., Papavizas, G. C. \& Diem, A. F. (1966). Polygalacturonate trans-eliminase and polygalacturonase production by Rhizoctonia solani. Phytopathology 56, 1006-1011.

BARASH, I. \& KLEIN, L. (1969). The surface localization of polygalacturonase in spores of Geotrichum candidum. Phytopathology 59, 319-324.

Barash, I., Zilberman, E. \& Marcus, L. (1984). Purification of Geotrichum candidum endopolygalacturonase from culture and from host tissue by affinity chromatography on cross-linked polypectate. Physiological Plant Pathology 25, 161-169.

Burton, E. G. \& Metzenberg, R. L. (1974). Properties of represssible alkaline phosphatase from wild type and wall-less mutant of Neurospora crassa. Journal of Biological Chemistry 249, 4679-4688.

Chamier, A.-C. \& Dixon, P. A. (1982). Pectinases in leaf degradation by aquatic hyphomycetes: the enzyme and leaf maceration. Journal of General Microbiology 128, 2469-2483.

COHEN, B. L. \& DRUCKER, H. (1977). Regulation of exocellular protease in Neurospora crassa: Induction and repression under conditions of nitrogen starvation. Archives of Biochemistry and Biophysics 182, 601-613.

Collmer, A., Ried, J. L. \& Mount, M. S. (1988). Assay methods for pectic enzymes. Methods in Enzymology 161, 326-335.

CoOke, R. D., Ferber, C. E. \& Kanagasabapathy, L. (1976). Purification and characterization of polygalacturonase from a commercial Aspergillus niger preparation. Biochimica et Biophysica Acta 452, 440-451.

COOPER, R. M. \& WOOD, R. K. S. (1973). Induction of synthesis of extracellular cell-wall degrading enzymes in vascular wilt fungi. Nature, London 246, 309-311.

DAvis, B. J. (1964). Disc electrophoresis. II. Method and application to human serum proteins. Annals of the New York Academy of Sciences 121, 404-427.

De Lorenzo, G., Salvi, G., Degrà, L., D'Ovidio, R. \& Cervone, F. (1987). Induction of extracellular polygalacturonase and its mRNA in the phytopathogenic fungus Fusarium moniliforme. Journal of General Microbiology 133, 3365-3373.

Dubois, M., Gilles, K. A., Hamilton, J. K., Rebers, P. A. \& Smith, F. (1956). Colorimetric method for determination of sugars and related substances. Analytical Chemistry 28, 350-356.

EBERHART, B. M. \& BECK, R. S. (1973). Induction of $\beta$-glucosidase in Neurospora crassa. Journal of Bacteriology 116, 295-303.

Eberhart, B. M., BeCK, R. S. \& Goolsby, K. M. (1977). Cellulase of Neurospora crassa. Journal of Bacteriology 130, 181-186.

Fanellit, C., CaCaCe, M. G. \& Cervone, F. (1978). Purification and properties of two polygalacturonases from Trichoderma koningii. Journal of General Microbiology 104, 305-309.

Fontana, J. D., Gebara, M., Blumel, M., Schneider, H., MackenZIE, C. R. \& JoHnson, K. G. (1988). $\alpha-4-O$-Methyl-D-glucuronidase component of xylanolytic complexes. Methods in Enzymology 160, 560-571.

Gratzner, H. G. \& Sheehan, D. N. (1969). Neurospora mutant exhibiting hyperproduction of amylase and invertase. Journal of Bacteriology 97, 544-549.

Gysler, C., Harmsen, J. A. M., Kester, H. C. M., Visser, J. \& Heim, J. (1990). Isolation and structure of the pectin lyase D-encoding gene from Aspergillus niger. Gene 89, 101-108.

Khanh, N. Q., Albrecht, H., RutTKowski, E., Löffler, F., GotTSChalK, M. \& JaNY, K.-D. (1990). Nucleotide and derived amino acid sequence of a pectinesterase cDNA isolated from Aspergillus niger strain R.H. 5344. Nucleic Acids Research 18, 4262.

LEONE, G. \& VAN DEN HEUVEL, J. (1987). Regulation by carbohydrates of the sequential 'in vitro' production of pectic enzymes by Botrytis cinerea. Canadian Journal of Botany 65, 2133-2141.

LindBerg, R. A. \& DRUCKER, H. (1984). Characterization and comparison of a Neurospora crassa RNAse purified from cultures undergoing each of three different states of derepression. Journal of Bacteriology 157, 375-379.

Lisker, N., Katan, J. \& Henis, Y. (1975). Sequential production of polygalacturonase, cellulase, and pectin lyase by Rhizoctonia solani. Canadian Journal of Microbiology 21, 1298-1304.

Manachini, M. G., Fortina, C. \& Parini, C. (1987). Purification and properties of an endopolygalacturonase produced by Rhizopus stolonifer. Biotechnology Letters 9, 219-224.

Marcus, L., Barash, I., SNeh, B., Koltin, Y. \& Finkler, A. (1986). Purification and characterization of pectolytic enzymes produced by virulent and hipovirulent isolates of Rhizoctonia solani Kuhn. Physiological and Molecular Plant Pathology 29, 325-336.

Martinez, M. J., Martinez, R. \& Reyes, F. (1988). Effect of pectin on pectinases in autolysis of Botrytis cinerea. Mycopathologia 102, 37-43.

MilleR, G. L. (1959). Use of dinitrosalicylic acid reagent for determination of reducing sugars. Analytical Biochemistry 31, 426-428.

Mishra, C., Keskar, S. \& Rao, M. (1984). Production and properties of extracellular endoxylanase from Neurospora crassa. Applied and Environmental Microbiology 48, 224-228.

NAGEL, C. W. \& ANDERSON, M. M. (1965). Action of a bacterial transeliminase on normal and unsaturated oligogalacturonic acids. Archives of Biochemistry and Biophysics 112, 322-330.

Pietro, R. C. L. R., Jorge, J. A. \& Terenzi, H. F. (1990). Effects of cell wall deficiency in 'slime' strains of Neurospora crassa: a study on mycelial and wall-less phenotypic derivatives of a single $f z ; s g ; o s-1$ ('slime'-like) segregant. Journal of General Microbiology 136, 121-129.

PITT, D. (1988). Pectin lyase from Phoma medicaginis var. pinodella. Methods in Enzymology 161, 350-354.

Polizeli, M. L. T. M., Pietro, R. C. L. R., Jorge, J. A. \& Terenzi, H. F. (1990). Effects of cell wall deficiency on the synthesis of polysaccharide-degrading exoenzymes. A study on mycelial and wall-less phenotypes of the $f z, s g, o s-1$ ('slime') triple mutant of Neurospora crassa. Journal of General Microbiology 136, 1463-1468.

Roboz, E., Barratt, R. W. \& TATUM, E. L. (1952). Breakdown of pectic substances by a new enzyme from Neurospora. Journal of Biological Chemistry 195, 459-471.

Rombouts, F. M. \& PILNIK, W. (1980). Pectic enzymes. In Economic Microbiology, vol. 5, 227-282. Edited by A. H. Rose. Academic Press: London. 
Ruttkowski, E., Labitzke, R., Khanh, N. Q., Löffler, F., GoTTSCHALK, M. \& JANY, K. D. (1990). Cloning and DNA sequence analysis of a polygalacturonase cDNA from Aspergillus niger R.H. 5344. Biochimica et Biophysica Acta 1087, 104-106.

Sigmund, R. D., McNally, M. T., Lee, D. B. \& Free, S. J. (1985) Neurospora glucamylase and a mutant affected in its regulation. Biochemical Genetics 23, 89-103.

SWANK, R. W. \& MUNKRES, K. D. (1971). Molecular weight analysis of oligopeptides by electrophoresis in polyacrylamide gel with sodium dodecyl sulphate. Analytical Biochemistry 39, 462-477.

Swinburne, T. R. \& Corden, M. E. (1967). Dissociation and recombination of a polygalacturonase complex during ion exchange chromatography. Nature, London 213, 286-287.
VogEL, H. J. (1964). Distribution of lysine pathways among fungi: evolutionary implications. American Naturalist 98, 435-446.

WaNG, M. C. \& KeEN, N. T. (1970). Purification and characterization of endopolygalacturonase from Verticillium albo-atrum. Archives of Biochemistry and Biophysics 141, 749-757.

White, C. A. \& KenNedy, J. F. (1988). The carbohydrate-directed enzymes. In Carbohydrate Chemistry, pp. 343-377. Edited by J. F. Kennedy. Clarendon Press: Oxford.

YAZDI, M. T., WoODWARD, J. R. \& RADFORD, A. (1990). The cellulase complex of Neurospora crassa: activity, stability and release. Journal of General Microbiology 136, 1313-1319. 